\title{
lamia majanohamensis gen. nov., sp. nov., an actinobacterium isolated from sea cucumber Holothuria edulis, and proposal of lamiaceae fam. nov.
}

Correspondence Midori Kurahashi kuramido@iam.u-tokyo.ac.jp

\author{
Midori Kurahashi, ${ }^{1}$ Yukiyo Fukunaga, ${ }^{1,2}$ Yayoi Sakiyama, ${ }^{2}$ \\ Shigeaki Harayama ${ }^{2}$ and Akira Yokota ${ }^{1}$
${ }^{1}$ Institute of Molecular and Cellular Biosciences, The University of Tokyo, Yayoi 1-1-1, Bunkyo-ku, Tokyo 113-0032, Japan \\ ${ }^{2}$ NITE Biological Resource Center (NBRC), National Institute of Technology and Evaluation (NITE), \\ 2-5-8 Kazusa-kamatari, Kisarazu-shi, Chiba 292-0818, Japan
}

\begin{abstract}
A novel, Gram-positive bacterial strain, $\mathrm{F}_{12}{ }^{\top}$, was isolated from the abdominal epidermis of a sea cucumber, Holothuria edulis, collected from seawater off the coast of Japan. According to 16S rRNA gene sequence analysis, this strain represents a novel, deep-rooting lineage within the class Actinobacteria and clusters with uncultured bacteria and Acidimicrobium ferrooxidans.

Compared to species with validly published names, the highest $16 \mathrm{~S}$ rRNA gene sequence similarity (89.8\%) was to Acidimicrobium ferrooxidans DSM $10331^{\top}$. Phylogenetic analyses showed that strain $\mathrm{F} 12^{\top}$ represents a distinct phylogenetic lineage related closely to the genus Acidimicrobium. Strain $\mathrm{F} 12^{\top}$ contained $\mathrm{MK}-9\left(\mathrm{H}_{6}\right)$ as the major menaquinone, whilst $17: 0$, $17: 1 \omega 8 c, 15: 0$ and $16: 0$ were the major cellular fatty acids. The cell-wall peptidoglycan of strain $\mathrm{F} 12^{\top}$ was composed of meso-diaminopimelic acid as the diagnostic diamino acid, alanine and glutamic acid $(1: 2: 1)$. The cell-wall sugars detected were rhamnose, mannose, arabinose, galactose and xylose. The $G+C$ content of the DNA was $74.4 \mathrm{~mol} \%$. From the taxonomic data obtained in this study, the name lamia majanohamensis gen. nov., sp. nov. is proposed for the isolate, with type strain $\mathrm{F} 12^{\top}$ (=NBRC $\left.102561^{\top}=\mathrm{DSM} 19957^{\top}\right)$. The name lamiaceae fam. nov. is also proposed for the distinct phyletic line represented by the genus lamia.
\end{abstract}

We have turned our attention to the intestine and epidermis of marine creatures as a source of novel lineages of bacteria. In our previous studies, we have mainly used marine agar 2216 (MA; Becton Dickinson) as the isolation and cultivation medium. As a result, we isolated several novel-lineage bacteria: Agarivorans albus (Kurahashi \& Yokota, 2004), Pseudovibrio ascidiaceicola (Fukunaga et al., 2006), Endozoicomonas elysicola (Kurahashi \& Yokota, 2007a) and Tateyamaria omphalii (Kurahashi \& Yokota, 2007b). In this study we used SN medium, which is commonly used for algal cultivation, and a novel bacterial strain $\left(\mathrm{F} 12^{\mathrm{T}}\right)$, forming a deep branch with Acidimicrobium ferrooxidans in the order Acidimicrobiales, was isolated.

\footnotetext{
Abbreviations: DAP, diaminopimelic acid; ML, maximum likelihood; NJ, neighbour joining; TEM, transmission electron microscopy.

The GenBank/EMBL/DDBJ accession number for the 16S rRNA gene sequence of strain $F 12^{\top}$ is $A B 360448$.

A supplementary figure showing the general morphology of cells of strain $\mathrm{F} 12^{\top}$ is available with the online version of this paper.
}

Acidimicrobium strains are Gram-positive, rod-shaped bacteria that are found in warm, acidic, sulphur- or mineral sulphide-rich environments. Acidimicrobium ferrooxidans was originally described by Clark \& Norris (1996) and was subsequently placed in the subclass Acidimicrobidae (Stackebrandt et al., 1997), which contains only the order Acidimicrobiales, family Acidimicrobiaceae, genus Acidimicrobium and one species, Acidimicrobium ferrooxidans. Interestingly, Rheims et al. (1999) carried out molecular environmental studies and discovered the existence of several novel 16S rRNA gene sequence clusters with probable worldwide distribution in different terrestrial environments, forming several lineages deeply rooted to the order Acidimicrobiales. However, no novel species belonging to these clusters have been reported.

The strain used in this study was obtained from the abdominal epidermis of a sea cucumber, Holothuria edulis, which was collected off the coast of Aka Island, Okinawa prefecture, Japan, at a depth of $6 \mathrm{~m}$, as described previously (Kurahashi \& Yokota, 2004). The medium used for isolation of strain $\mathrm{F} 12^{\mathrm{T}}$ was SN medium, consisting of 
750 p.p.m. $\mathrm{NaNO}_{3}, 15.9$ p.p.m. $\mathrm{K}_{2} \mathrm{HPO}_{4}, 5.6$ p.p.m. disodium EDTA dihydrate, 10.4 p.p.m. $\mathrm{Na}_{2} \mathrm{CO}_{3}, 1.0$ p.p.m. vitamin $\mathrm{B}_{12}$ and 1.0 p.p.m. Cyano trace metal solution [(1 distilled water $)^{-1}$ : $6.25 \mathrm{~g}$ citric acid. $\mathrm{H}_{2} \mathrm{O}, 6.0 \mathrm{~g}$ ferric ammonium citrate, $1.4 \mathrm{~g} \quad \mathrm{MnCl}_{2} .4 \mathrm{H}_{2} \mathrm{O}, \quad 0.39 \mathrm{~g}$ $\mathrm{Na}_{2} \mathrm{MoO}_{4} \cdot 2 \mathrm{H}_{2} \mathrm{O}, 0.025 \mathrm{~g} \mathrm{Co}\left(\mathrm{NO}_{3}\right)_{2} \cdot 6 \mathrm{H}_{2} \mathrm{O}$ and $0.222 \mathrm{~g}$ $\left.\mathrm{ZnSO}_{4} \cdot 7 \mathrm{H}_{2} \mathrm{O}\right]$ in filtered $75 \%$ seawater. The strain cultures were maintained routinely on MA at $25{ }^{\circ} \mathrm{C}$.

Phenotypic and chemotaxonomic characteristics were determined by using $\mathrm{MA}$ at $30{ }^{\circ} \mathrm{C}$ unless otherwise indicated. Colony morphology, size and colour were examined by using cultures grown aerobically after 3 weeks incubation. Salt tolerance was tested in R2AM medium [ ( 1 distilled water) ${ }^{-1}: 18.2 \mathrm{~g} \mathrm{R} 2 \mathrm{~A}$ agar, $10.0 \mathrm{~g} \mathrm{MgCl}_{2} \cdot 6 \mathrm{H}_{2} \mathrm{O}$, $6.0 \mathrm{~g} \mathrm{MgSO}_{4} \cdot 7 \mathrm{H}_{2} \mathrm{O}, 2.0 \mathrm{~g} \mathrm{CaCl}_{2} \cdot 2 \mathrm{H}_{2} \mathrm{O}$ and $\left.0.6 \mathrm{~g} \mathrm{KCl}\right]$ supplemented with $0-12 \%(\mathrm{w} / \mathrm{v}) \mathrm{NaCl}$ after 3 weeks incubation at $30{ }^{\circ} \mathrm{C}$. Gram reaction was determined by using a Gram Stain kit (Becton Dickinson), following the manufacturer's instructions. Cell motility and morphology were studied by using phase-contrast microscopy and transmission electron microscopy (TEM), respectively. Specimens for TEM were negatively stained with phosphotungstic acid. Catalase activity was determined by dropping $3 \% \mathrm{H}_{2} \mathrm{O}_{2}$ onto colonies, and oxidase-detection strips (bioMérieux) were used for the oxidase test. Biochemical analyses were performed by inoculating API 20E strips (bioMérieux), a microbial identification product. Instructions of the manufacturer were followed, except that inocula for API $20 \mathrm{E}$ were prepared in artificial seawater. Results are given in the species description below. Respiratory quinones were extracted with chloroform : methanol $(2: 1, \mathrm{v} / \mathrm{v})$, fractionated on a spin column and determined by LC-MS using an LCMS-QP8000 $\alpha$ (Shimadzu). Chemotaxonomic analyses of the $\mathrm{G}+\mathrm{C}$ content of the DNA and whole-cell fatty acids were performed as described previously (Kurahashi \& Yokota, 2004). The whole-cell fatty acid methyl ester profile was determined by using the MIDI Sherlock Microbial Identification system (Microbial ID). Note, however, that Acidimicrobium ferrooxidans DSM $10331^{\mathrm{T}}$ was cultured on Acidimicrobium medium $\left[(1 \text { distilled water })^{-1}: 0.5 \mathrm{~g}\right.$ $\mathrm{MgSO}_{4}, 0.4 \mathrm{~g}\left(\mathrm{NH}_{4}\right)_{2} \mathrm{SO}_{4}, 0.2 \mathrm{~g} \mathrm{~K}_{2} \mathrm{HPO}_{4}$ and $0.1 \mathrm{~g} \mathrm{KCl}$, adjusted to $\mathrm{pH} 2.0$ with $\left.\mathrm{H}_{2} \mathrm{SO}_{4}\right]$ at $45^{\circ} \mathrm{C}$. Fatty acids unidentified by MIDI were analysed by using GC-MS (Agilent). After cells were cultured for 3 weeks at $30{ }^{\circ} \mathrm{C}$ on $\mathrm{MA}$, cell walls were isolated and purified by using the method of Schleifer \& Kandler (1972). The amino acid and sugar compositions of cell-wall hydrolysates (Becker et al., 1965) were analysed by TLC (Hasegawa et al., 1983) and HPLC as described by Takeuchi et al. (1999). The $N$-acyl type of muramic acid was determined by the colorimetric method of Uchida \& Aida (1977).

Sequencing of the $16 \mathrm{~S}$ rRNA gene was carried out as described previously (Kurahashi \& Yokota, 2004). 16S rRNA gene sequence similarity was investigated by using the FASTA program (Pearson, 1994). Alignments of $16 \mathrm{~S}$ rRNA gene sequences of the isolate and related strains were carried out with CLUSTAL W software (version 1.8) (Thompson et al., 1994). The evolutionary-distance matrix was calculated by using the Kimura two-parameter method (Kimura, 1980). Phylogenetic trees were constructed by using two different methods, the neighbour-joining (NJ; Saitou \& Nei, 1987) and maximum-likelihood (ML; Felsenstein, 1981) algorithms. The topology of the phylogenetic tree was evaluated by bootstrap analysis with 1000 sample replications according to the method of Felsenstein (1993).

Cells of strain $\mathrm{F} 12^{\mathrm{T}}$ possessed a Gram-positive cell wall and were non-spore-forming and non-motile. Cells were rodshaped and had lengths ranging from 1.2 to $1.7 \mu \mathrm{m}$ and widths from 0.3 to $0.5 \mu \mathrm{m}$. Colonies on MA after 3 weeks at $30{ }^{\circ} \mathrm{C}$ were circular, convex, white in colour, nearly opaque and usually $0.2-0.3 \mathrm{~mm}$ in diameter. Growth was observed at $15-40{ }^{\circ} \mathrm{C}$, with an optimum between 28 and $30{ }^{\circ} \mathrm{C}$. Growth occurred at $\mathrm{pH} 6-9$, with an optimum at $\mathrm{pH}$ 7. Electron microscopic investigations suggested that the isolate showed transverse and binary fission in cells, as a result of cell division (see Supplementary Fig. S1, available in IJSEM Online).

Strain $\mathrm{F} 12^{\mathrm{T}}$ contained MK-9 $\left(\mathrm{H}_{6}\right)$ as the predominant menaquinone $(78.3 \%)$ and MK-9 $\left(\mathrm{H}_{4}\right)$, MK-9 $\left(\mathrm{H}_{8}\right)$, MK$9\left(\mathrm{H}_{2}\right)$ and MK-9 $\left(\mathrm{H}_{0}\right)$ as the minor menaquinones (5.6, $2.4,1.0$ and $0.6 \%$, respectively). The DNA G $+\mathrm{C}$ content of $\mathrm{F} 12^{\mathrm{T}}$ was found to be $74.4 \mathrm{~mol} \%$, higher than that of Acidimicrobium ferrooxidans (67.0-68.5 mol\%). The cellular fatty acid composition of strain $\mathrm{F} 12^{\mathrm{T}}$ was dominated by $17: 0(18.4 \%), 17: 1 \omega 8 c(13.1 \%), 15: 0(9.9 \%)$ and $16: 0(9.7 \%)$, a profile different from that of the closely related genus Acidimicrobium (Table 1). The cell wall of strain $\mathrm{F} 12^{\mathrm{T}}$ consisted of glutamic acid:alanine: mesodiaminopimelic acid (DAP) in a ratio of $1: 2: 1$; this corresponds to peptidoglycan type Al $\gamma$ according to Schleifer \& Kandler (1972). The cell-wall muramic acid was of the glycolyl type. The cell-wall sugars of strain $\mathrm{F} 12^{\mathrm{T}}$ were rhamnose, mannose, arabinose, galactose and xylose.

An almost-complete 16S rRNA gene sequence for strain $\mathrm{F} 12^{\mathrm{T}}$ was determined and the FAST search in GenBank showed that the strain belongs to the class Actinobacteria. All species with validly published names exhibited $<90 \%$ sequence similarity to the newly determined sequence. Strain $\mathrm{F} 12^{\mathrm{T}}$ displayed closest sequence similarity to Acidimicrobium ferrooxidans DSM $10331^{\mathrm{T}}$ (GenBank accession no. U75647, $89.8 \%$ similarity). Isolate $\mathrm{F} 12^{\mathrm{T}}$ is equally closely related to 'Candidatus Microthrix parvicella' EU19 (GenBank accession no. DQ147285, $89.8 \%$ similarity; Blackall et al., 1995). However, 'Candidatus Microthrix parvicella' could not be stored successfully and physiological tests failed, due to its poor growth on artificial media. Phylogenetic trees obtained by using the NJ (Fig. 1) and ML (data not shown) methods revealed clear affiliations of the novel isolate with the uncultured isolates 101-26 (GenBank accession no. EF157223, $96.3 \%$ similar- 
Table 1. Cellular fatty acid compositions (\%) of strain $\mathrm{F} 12^{\top}$ and Acidimicrobium ferrooxidans DSM $10331^{\top}$

Strains: $1, \mathrm{~F} 12^{\mathrm{T}} ; 2$, Acidimicrobium ferrooxidans DSM $10331^{\mathrm{T}}$ (data from present study).,$-<0.1 \%$ or not detected.

\begin{tabular}{|c|c|c|}
\hline Fatty acid & 1 & 2 \\
\hline \multicolumn{3}{|l|}{ Saturated straight-chain } \\
\hline $14: 0$ & 1.6 & 0.2 \\
\hline $15: 0$ & 9.9 & - \\
\hline $16: 0$ & 9.7 & 1.0 \\
\hline $17: 0$ & 18.4 & - \\
\hline $18: 0$ & 8.2 & - \\
\hline $19: 0$ & 0.7 & - \\
\hline \multicolumn{3}{|c|}{ Unsaturated straight-chain } \\
\hline $16: 1 \omega 7 c$ & 2.3 & - \\
\hline $16: 1 \omega 5 c$ & 8.5 & - \\
\hline $17: 1 \omega 9 c$ & 0.4 & - \\
\hline $17: 1 \omega 8 c$ & 13.1 & - \\
\hline $17: 1 \omega 6 c$ & 1.8 & - \\
\hline $18: 1 \omega 9 c$ & 4.3 & - \\
\hline $18: 1 \omega 7 c$ & 3.2 & - \\
\hline $18: 1 \omega 5 c$ & 0.6 & - \\
\hline $18: 3 \omega 6 c(6,9,12)$ & & 0.1 \\
\hline \multicolumn{3}{|l|}{ Branched } \\
\hline iso $14: 0$ & - & 0.3 \\
\hline iso $15: 0$ & - & 4.1 \\
\hline anteiso $15: 0$ & - & 1.3 \\
\hline iso $\mathrm{h} 16: 1$ & 1.7 & - \\
\hline iso $16: 0$ & 8.2 & 83.3 \\
\hline iso $17: 0$ & - & 1.3 \\
\hline anteiso $17: 0$ & - & 7.8 \\
\hline iso $18: 0$ & 1.3 & - \\
\hline cyclo $19: 0 \omega 8 c$ & 1.1 & - \\
\hline 10-methyl $17: 0$ & 1.4 & - \\
\hline \multicolumn{3}{|l|}{ Hydroxy branched } \\
\hline iso $14: 03-\mathrm{OH}$ & - & 0.4 \\
\hline \multicolumn{3}{|l|}{ Unknown } \\
\hline ECL $14.959^{*}$ & 3.7 & - \\
\hline Summed feature $3 \dagger$ & - & 0.1 \\
\hline
\end{tabular}

${ }^{\star}$ ECL, Equivalent chain length.

$\dagger$ Summed feature 3 comprises $\mathrm{C} 16: 1 \omega 7 c$ and/or iso $\mathrm{C} 15: 0$ 2-OH.

ity; Kim \& Crowley, 2007) and AKIW1115 (GenBank accession no. DQ129371, 94.8\% similarity; Brodie et al., 2007) and placed the novel strain on a separate branch within the order Acidimicrobiales.

Characteristics that differentiate strain $\mathrm{F} 12^{\mathrm{T}}$ from members of phylogenetically related genera are shown in Table 2 . Strain $\mathrm{F} 12^{\mathrm{T}}$ differs from members of the genera Frankia and Geodermatophilus in several characteristics. Strain $\mathrm{F} 12^{\mathrm{T}}$ contains meso-DAP in the cell-wall peptidoglycan and MK$9\left(\mathrm{H}_{6}\right)$ as the predominant menaquinone in the cell membrane, whereas Acidimicrobium ferrooxidans possesses MK-9 $\left(\mathrm{H}_{8}\right)$ and members of the genus Sporichthya possess LL-DAP. There is $>10 \%$ difference in the DNA G $+\mathrm{C}$ content of strain $\mathrm{F} 12^{\mathrm{T}}$ and those of members of the genus Acidothermus. The results of the treeing analyses showed that isolate $\mathrm{F} 12^{\mathrm{T}}$ formed a distant monophyletic clade with cloned sequences within the order Acidimicrobiales, as indicated by the $100 \%$ bootstrap value, and this clade was not closely associated with any other taxon.

On the basis of the phenotypic and genotypic characteristics described above, strain $\mathrm{F} 12^{\mathrm{T}}$ is proposed as the type strain of Iamia majanohamensis gen. nov., sp. nov. We also propose Iamiaceae fam. nov., based on the distinct phylogenetic position of Iamia majanohamensis gen. nov., sp. nov. within the order Acidimicrobiales.

\section{Description of lamia gen. nov.}

Iamia (I.a'mi.a. N.L. fem. n. Iamia arbitrary name formed from the acronym of the Institute of Applied Microbiology at the University of Tokyo, which has made significant contributions to microbiology).

Cells are Gram-positive, non-endospore-forming rods that are non-motile. Colonies grow aerobically, but not anaerobically. In media devoid of sodium chloride, growth is observed. Oxidase- and catalase-positive. The predominant menaquinone is MK- $9\left(\mathrm{H}_{6}\right)$. Cell wall contains glutamic acid, alanine and meso-DAP. The peptidoglycan type is presumed to be $\mathrm{A} 1 \gamma$. The peptidoglycan is of the glycolyl type. The major cellular fatty acids are 17:0, $17: 1 \omega 8 c, 15: 0$ and 16:0. The type species is Iamia majanohamensis.

\section{Description of lamia majanohamensis sp. nov.}

Iamia majanohamensis (ma.ja.no.ha.men'sis. N.L. fem. adj. majanohamensis pertaining to Majanohama, the site on the coast of Aka Island, Japan, where the type strain was isolated).

In addition to the properties given in the genus description, cells are $1.2-1.7 \times 0.3-0.5 \mu \mathrm{m}$ in size. Colonies on MA are small, white, circular, convex, smooth, shiny and $0.2-0.3 \mathrm{~mm}$ in diameter after 3 weeks incubation at $30{ }^{\circ} \mathrm{C}$. Optimal growth temperature is $28-30{ }^{\circ} \mathrm{C}$. No growth occurs at temperatures above $45^{\circ} \mathrm{C}$ or below $10{ }^{\circ} \mathrm{C}$. Hydrolysis of gelatin is observed. Cell-wall sugars are rhamnose, mannose, arabinose, galactose and xylose. Positive for catalase, oxidase, arginine dihydrolase, lysine decarboxylase, ornithine decarboxylase, production of acetoin and gelatinase and reduction of nitrate to $\mathrm{N}_{2}$, but negative for $\beta$-galactosidase, urease, tryptophan deaminase, utilization of citrate, production of $\mathrm{H}_{2} \mathrm{~S}$ and indole and assimilation of amygdalin, arabinose, D-glucose, inositol, D-mannose, melibiose, rhamnose, sucrose and sorbitol. The DNA G $+\mathrm{C}$ content is $74.4 \mathrm{~mol} \%$.

The type strain, $\mathrm{F} 12^{\mathrm{T}}\left(=\right.$ NBRC $\left.102561^{\mathrm{T}}=\mathrm{DSM} 19957^{\mathrm{T}}\right)$, was isolated from the ventral epidermis of the sea cucumber Holothuria edulis at Aka Island, Okinawa, Japan. 


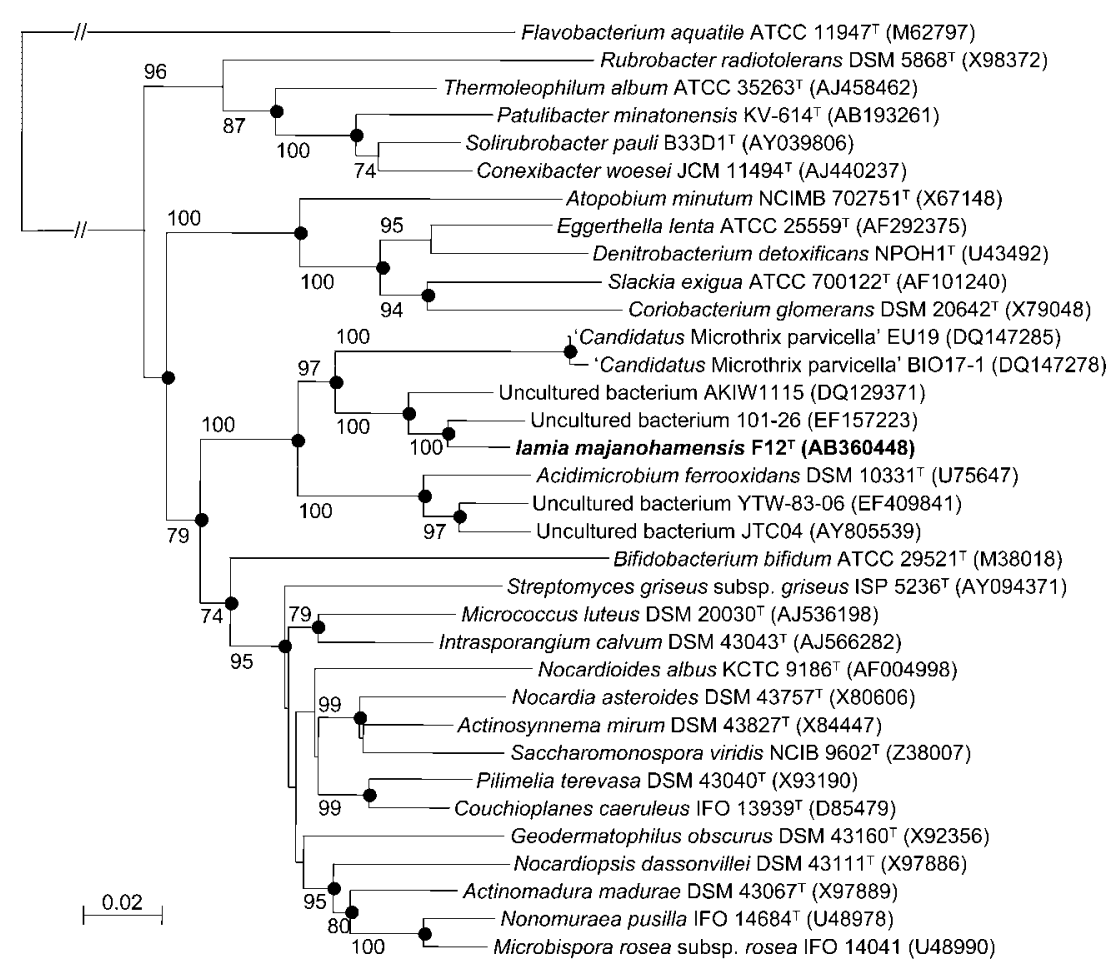

Fig. 1. NJ tree showing the phylogenetic positions of strain $\mathrm{F} 12^{\top}$ and related organisms, inferred from 16S rRNA gene sequence analyses. Bootstrap values $>70 \%$ (percentage of 1000 bootstrap resamplings) are indicated. indicates recovered nodes with $>70 \%$ bootstrap value in an ML tree. Flavobacterium aquatile ATCC $11947^{\top}$ (M62797) was used as an outgroup to define the root of the tree. Bar, 0.02 substitutions per nucleotide position.

\section{Description of lamiaceae fam. nov.}

Iamiaceae (I.a.mi.a'ce.ae. N.L. fem. n. Iamia type genus of the family; -aceae ending to denote a family; N.L. fem. n. Iamiaceae the family of Iamia).
Segregation of these organisms into a novel family is justified by their distinct phyletic lineage based on the $16 \mathrm{~S}$ rRNA gene. The pattern of $16 \mathrm{~S}$ rRNA gene sequence signature nucleotides of members of the family consists of 408-434 (G-C), 722-733 (G-G), 1118-1155 (U-A), 443-

Table 2. Differential characteristics of strain $\mathrm{F} 12^{\top}$ and members of related genera

Taxa: 1, strain F12 ${ }^{\mathrm{T}}$ (data from this study); 2, Acidimicrobium (Clark \& Norris, 1996; Normand, 2006); 3, Frankia (Normand et al., 1996); 4, Geodermatophilus (Normand et al., 1996); 5, Sporichthya (Rainey et al., 1993; Tamura et al., 1999); 6, Acidothermus (Mohagheghi et al., 1986). ND, No data available; -, negative; +, positive.

\begin{tabular}{|c|c|c|c|c|c|c|}
\hline Hyphae & - & $-{ }^{*}$ & + & + & $+1-$ & - \\
\hline Motility & - & $-{ }^{*}$ & - & $+1-$ & $+1-$ & - \\
\hline Growth at $\mathrm{pH} 2$ & - & + & - & $\mathrm{ND}$ & $\mathrm{ND}$ & - \\
\hline \multicolumn{7}{|l|}{ Growth temperature $\left({ }^{\circ} \mathrm{C}\right)$} \\
\hline Optimum & $25-30$ & $45-50$ & $25-30$ & $24-28$ & $20-30$ & $50-60$ \\
\hline Oxidase & + & $+^{*}$ & ND & ND & $\mathrm{ND}$ & - \\
\hline Catalase & + & $-{ }^{*}$ & + & + & $\mathrm{ND}$ & + \\
\hline Nitrate reduction & + & ND & - & $+1-$ & + & - \\
\hline Cell-wall type & meso-DAP & meso-DAP & meso-DAP & meso-DAP & LL-DAP & meso-DAP \\
\hline Major menaquinone & $\begin{array}{l}\text { MK-9 }\left(\mathrm{H}_{6}\right), \text { MK- } \\
9\left(\mathrm{H}_{4}\right), \text { MK- } 9\left(\mathrm{H}_{8}\right)\end{array}$ & MK- $9\left(\mathrm{H}_{8}\right)^{*}$ & MK-9 $\left(\mathrm{H}_{4}\right)$ & MK-9 $\left(\mathrm{H}_{4}\right)$ & $\begin{array}{r}\text { MK-9 }\left(\mathrm{H}_{6}\right) \\
\text { MK-9 }\left(\mathrm{H}_{8}\right)\end{array}$ & $\mathrm{ND}$ \\
\hline
\end{tabular}

*This study. 
491 (U-A), 1165-1171 (G-C) and 1263-1272 (A-U). The type genus is Iamia.

\section{Acknowledgements}

We thank Dr Jean P. Euzéby (Ecole Nationale Veterinaire, France) for his help in the latinization of the novel genus and species names. This work was supported in part by a Grant-in-Aid for Scientific Research (no. 17310135) from the Ministry of Education, Culture, Sports, Science, and Technology of Japan. Y. F., Y.S. and S. H. thank the New Energy and Industrial Technology Development Organization for financial support.

\section{References}

Becker, B., Lechevalier, M. P. \& Lechevalier, H. A. (1965). Chemical composition of cell-wall preparations from strains of various formgenera of aerobic actinomycetes. Appl Microbiol 13, 236-243.

Blackall, L. L., Seviour, E. M., Cunningham, M. A., Seviour, R. J. \& Hugenholtz, P. (1995). 'Microthrix parvicella' is a novel, deep branching member of the actinomycetes subphylum. Syst Appl Microbiol 17, 513-518.

Brodie, E. L., DeSantis, T. Z., Moberg Parker, J. P., Zubietta, I. X., Piceno, Y. M. \& Andersen, G. L. (2007). Urban aerosols harbor diverse and dynamic bacterial populations. Proc Natl Acad Sci U S A 104, 299-304.

Clark, D. A. \& Norris, P. R. (1996). Acidimicrobium ferrooxidans gen. nov., sp. nov.: mixed-culture ferrous iron oxidation with Sulfobacillus species. Microbiology 142, 785-790.

Felsenstein, J. (1981). Evolutionary trees from DNA sequences: a maximum likelihood approach. J Mol Evol 17, 368-376.

Felsenstein, J. (1993). PHYLIP (phylogeny inference package), version 3.5c. Distributed by the author. Department of Genome Sciences, University of Washington, Seattle, WA, USA.

Fukunaga, Y., Kurahashi, M., Tanaka, K., Yanagi, K., Yokota, A. \& Harayama, S. (2006). Pseudovibrio ascidiaceicola sp. nov., isolated from ascidians (sea squirts). Int J Syst Evol Microbiol 56, 343-347.

Hasegawa, T., Takizawa, M. \& Tanida, S. (1983). A rapid analysis for chemical grouping of aerobic actinomycetes. J Gen Appl Microbiol 29 , 319-322.

Kim, J. S. \& Crowley, D. E. (2007). Microbial diversity in natural asphalts of the rancho la brea tar pits. Appl Environ Microbiol 73, 4579-4591.

Kimura, M. (1980). A simple method for estimating evolutionary rates of base substitutions through comparative studies of nucleotide sequences. J Mol Evol 16, 111-120.

Kurahashi, M. \& Yokota, A. (2004). Agarivorans albus gen. nov., sp. nov., a $\gamma$-proteobacterium isolated from marine animals. Int J Syst Evol Microbiol 54, 693-697.
Kurahashi, M. \& Yokota, A. (2007a). Endozoicomonas elysicola gen. nov., sp. nov., a $\gamma$-proteobacterium isolated from the sea slug Elysia ornate. Syst Appl Microbiol 30, 202-206.

Kurahashi, M. \& Yokota, A. (2007b). Tateyamaria omphalii gen. nov., sp. nov., an $\alpha$-proteobacterium isolated from a top shell Omphalius pfeifferi pfeifferi. Syst Appl Microbiol 30, 371-375.

Mohagheghi, A., Grohmann, K., Himmel, M., Leighton, L. \& Updegraff, D. M. (1986). Isolation and characterization of Acidothermus cellulolyticus gen. nov., sp. nov., a new genus of thermophilic, acidophilic, cellulolytic bacteria. Int J Syst Bacteriol 36, 435-443.

Normand, P. (2006). The families Frankiaceae, Geodermatophilaceae, Acidothermaceae and Sporichthyaceae. In The Prokaryotes, 3rd edn, pp. 669-681. Edited by M. Dworkin, S. Falkow, E. Rosenberg, K.-H. Schleifer \& E. Stackebrandt. New York: Springer.

Normand, P., Orso, S., Cournoyer, B., Jeannin, P., Chapelon, C., Dawson, J., Evtushenko, L. \& Misra, K. (1996). Molecular phylogeny of the genus Frankia and related genera and emendation of the family Frankiaceae. Int J Syst Bacteriol 46, 1-9.

Pearson, W. R. (1994). Using the FASTA program to search protein and DNA sequence databases. Methods Mol Biol 24, 307-331.

Rainey, F. A., Schumann, P., Prauser, H., Toalster, R. \& Stackebrandt, E. (1993). Sporichthya polymorpha represents a novel line of descent within the order Actinomycetales. FEMS Microbiol Lett 109, 263-269.

Rheims, H., Felske, A., Seufert, S. \& Stackebrandt, E. (1999). Molecular monitoring of an uncultured group of the class Actinobacteria in two terrestrial environments. J Microbiol Methods 36, 65-75.

Saitou, N. \& Nei, M. (1987). The neighbor-joining method: a new method for reconstructing phylogenetic trees. Mol Biol Evol 4, 406425.

Schleifer, K. H. \& Kandler, O. (1972). Peptidoglycan types of bacterial cell walls and their taxonomic implications. Bacteriol Rev 36, 407-477.

Stackebrandt, E., Rainey, F. A. \& Ward-Rainey, N. L. (1997). Proposal for a new hierarchic classification system, Actinobacteria classis nov. Int J Syst Bacteriol 47, 479-491.

Takeuchi, M., Sakane, T., Nihira, T., Yamada, Y. \& Imai, K. (1999). Corynebacterium terpenotabidum sp. nov., a bacterium capable of degrading squalene. Int J Syst Bacteriol 49, 223-229.

Tamura, T., Hayakawa, M. \& Hatano, K. (1999). Sporichthya brevicatena sp. nov. Int J Syst Bacteriol 49, 1779-1784.

Thompson, J. D., Higgins, D. G. \& Gibson, T. J. (1994). ClustaL W: improving the sensitivity of progressive multiple sequence aligment through sequence weighting, position-specific gap penalties and weight matrix choice. Nucleic Acids Res 22, 4673-4680.

Uchida, K. \& Aida, K. (1977). Acyl type of bacterial cell wall: its simple identification by colorimetric method. J Gen Appl Microbiol 23, 249260. 